\title{
Synthesis and Cellular Effect of a Novel Conjugate of Polyamide and Phospholipid
}

\author{
Yi Liu, ${ }^{a}$ Yulin Deng, ${ }^{b}$ Rong Zheng, ${ }^{a}$ Peilong Zhang, ${ }^{a}$ Hui Zhai, ${ }^{a}$ and Changjin Zhu ${ }^{*, a}$ \\ ${ }^{a}$ Department of Applied Chemistry, Beijing Institute of Technology; and ${ }^{b}$ School of Life Science and Biotechnology, \\ Beijing Institute of Technology; No. 5, Zhongguancun South Street, 100081 Beijing, China. \\ Received January 4, 2006; accepted March 13, 2006
}

\begin{abstract}
In order to improve the cell penetration of polyamide and its movement toward nucleic DNA we synthesized a conjugate of polyamide and phospholipid, which showed a significantly reducecd cytotoxicity and effective apoptosis when comparing with the native polyamide.
\end{abstract}

Key words polyamide; phospholipid conjugate; cytotoxicity; apoptosis

Small molecules with the ability to target predetermined sequences of DNA would be valuable tools in molecular biology and potentially in human medicine. ${ }^{1-3)}$ Synthetic polyamides consisting of $N$-methylpyrrole (Py) and $N$ methylimidazole (Im) have received special attention due to their high DNA affinity, sequence specificity, and relatively small size. ${ }^{4-6)}$ These polyamides have been shown to interfere with protein-DNA interactions, and have the potential to modulate gene expression by designing to recognize specific DNA sequences. ${ }^{5)}$ For polyamides to be effective in gene regulation, they must reach their target DNA inside the cell. 5,7$)$ However, there are few examples and only circumstantial evidence that suggest that polyamides bind to nuclear DNA targets in living eukaryotic cells. ${ }^{7-12)}$

In the present studies, we designed a conjugate in which a phosphatidylcholine (PC) was attached to the polyamide. The introduction of the phospholipid was expected to improve the permeability of the synthetic molecule through the cell membrane, guide the movement toward to nucleus in cells, and thereby reduce the cytotoxicity. The phospholipid is a primary component of biologicall membrane, and has proven to be noncytotoxic. In particular, the hydrophobic tail of the lipid is possible to greatly benefit the movement of the conjugate toward to nucleus in cells, and subsequently promote the interaction with nucleic DNA. ${ }^{13)}$

\section{Results and Discussion}

Polyamide $10\left(\mathrm{O}_{2} \mathrm{~N}\right.$-PyPy- $\beta$-PyPy- $\beta$-OEt $)$ and the targeted conjugate $13\left(\mathrm{O}_{2} \mathrm{~N}\right.$-PyPy- $\beta$-PyPy- $\beta$-PC) were synthesized as shown in Chart 1 . $\beta$-Alanine $(\beta)$ functioned as a spacer both in polyamide $\mathbf{1 0}$ and conjugate $\mathbf{1 3 . 1 0}$ is a regular structure among the synthetic polyamides. ${ }^{14,15)}$ Based on the DNAbinding study results of natural product distamycin and netropsin ${ }^{16,17)}$ and the pairing rules of polyamides binding to DNA derived by Dervan ${ }^{14}$ ) the polyamide $\mathbf{1 0}$ and the polyamide moiety in the designed conjugate $\mathbf{1 3}$ were presumed to have an ability of DNA-binding in $\mathrm{A} / \mathrm{T}$ and $\mathrm{T} / \mathrm{A}$ pairs rich region.

Primarily, DCC coupling method was used in the synthesis. ${ }^{18)}$ Direct coupling of $\beta$-alanine with pyrrole monomer $N$ methyl-4-nitro-2-trichloroacetylpyrrole $\mathbf{1}$ without any coupling reagent generated monomer derivative $\mathbf{4}$ and $\mathbf{5}$, from which dimeric pyrrole amide $\mathbf{6}$ and $\mathbf{8}$ were prepared, respectively. These two dimers were among the key building blocks in the present synthesis. In the preliminary experiment of tetrameric amide synthesis, coupling of acid 7 of the dimer with the amino dimer generated from the hydrogenation of 6 was presumed to give the methyl ester of the tetrameric amide, which would be the desired polyamide and would also serve as another key building block for the conjugate. However, hydrogenation of the nitro group of $\mathbf{6}$ by the catalysis of palladium on carbon formed many side-products rather than the desired one detected by TLC method. While ethyl ester $\mathbf{8}$, instead of $\mathbf{6}$, prepared by the same method as that for the preparation of $\mathbf{6}$ was used in the reaction the desired reduction product was obtained. This indicates that a degradation of the methyl ester (6) or its reduction product might occur during the reaction. The mechanism of this undesired reaction remained still uncleared now and is being studied using methods such as tandem electrospray ionization mass spectrometry.

Reaction of amine 9 generated from $\mathbf{8}$ by the hydrogenation with acid $\mathbf{7}$ produced ethyl ester $\mathbf{1 0}$ of the tetrameric polyamide in good yield. Coupling of acid $\mathbf{1 1}$ of the tetramer with lysophosphotidylcholine $\mathbf{1 2}$ in the presence of DMAP yielded the targeted conjugate $\mathbf{1 3}$.

The cytotoxicity of polyamide $\mathbf{1 0}$ and conjugate $\mathbf{1 3}$ in HeLa cells and SH-SY5Y neuroblastoma cells are described in Fig. 1. Both the compounds were toxic against HeLa cells and SH-SY5Y neuroblastoma cells. Their toxicity was raised with the increase of the concentration of compounds in the cell culture. However, at each of the concentrations, conjugate 13 always exhibited a lower cytotoxicity significantly than polyamide $\mathbf{1 0}$ in both two types of tumor cells. For example, at $150 \mu \mathrm{M}$ HeLa cells were inhibited by $11.6 \%$ by $\mathbf{1 3}$ whereas by $24.2 \%$ by 10 (Fig. 1a), while SH-SY5Y neuroblastoma cells were inhibited by $36.0 \%$ by $\mathbf{1 3}$ whereas by $57.5 \%$ by $\mathbf{1 0}$ (Fig. 1b). The cytotoxicity of $\mathbf{1 3}$ was lower about 5.1 to $21.5 \%$ than that of $\mathbf{1 0}$. Further analysis of the cytotoxicity data as described in Fig. 2 clearly shows cell proliferation inhibition by the two compounds in a concentration- and time-dependent manner. The viability of HeLa cells decreased with the incubation proceeding and the increase in the compound concentration. However the cells treated with $\mathbf{1 3}$ remarkably reveal a higher viability than that with $\mathbf{1 0}$ at each incubation time and concentration of the compounds. Obviously, combination of the phospholipid with the polyamide showed a significant cytotoxicity-reduced effect compared with the native polyamide. Further, in order to understand in mechanism the cell death or the cytotoxicity re- 


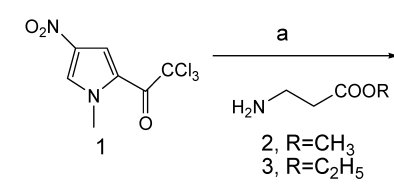<smiles>Cn1cc([N+](=O)[O-])cc1C(=O)NCCC(=O)O</smiles><smiles>Cn1cc([N+](=O)[O-])cc1C(=O)O</smiles><smiles>Cn1cc(NC(=O)c2cc(Br)cn2C)cc1C(=O)NCCC(=O)O</smiles>

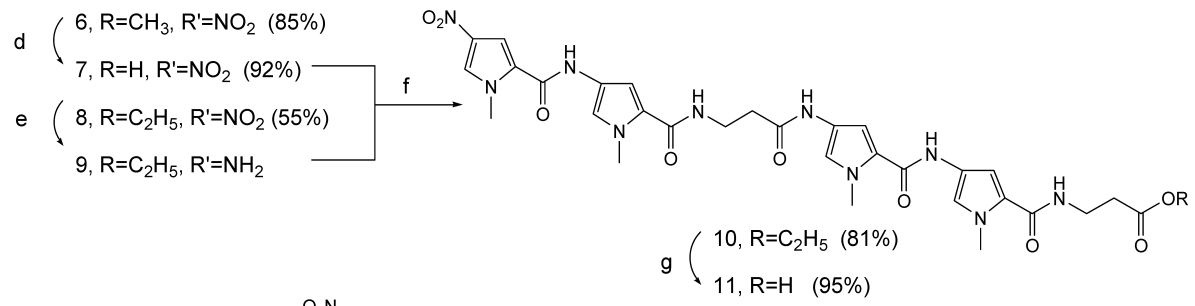

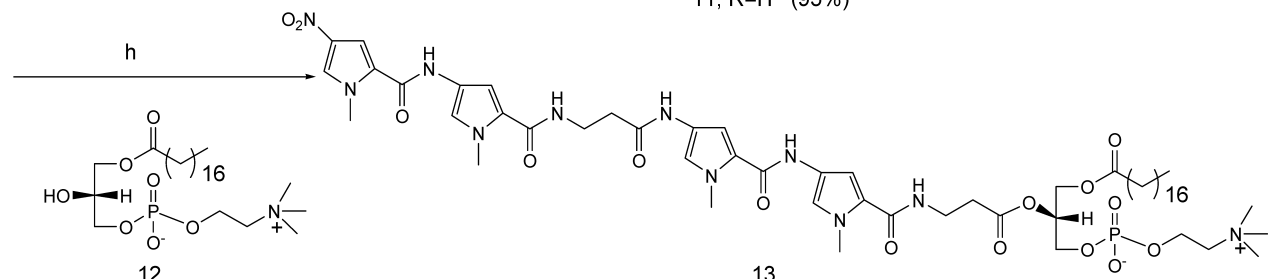

13

Reagents and conditions: (a) EtOAc, rt, $5 \mathrm{~h}$, re-crystallize from EtOH; (b) $\mathrm{Pd} / \mathrm{C}, \mathrm{H}_{2}, \mathrm{CH}_{3} \mathrm{OH}, \mathrm{rt}, 6 \mathrm{~h}$; (c) $\mathrm{HOBt} / \mathrm{DCC}, \mathrm{CHCl}$, rt, 8 h; $(\mathrm{d}) \mathrm{NaOH}, \mathrm{C}_{2} \mathrm{H}_{5} \mathrm{OH} / \mathrm{H}_{2} \mathrm{O}, \mathrm{rt}, 6 \mathrm{~h}$, then $\mathrm{HCl}$ (aq.); (e) Pd/C, $\mathrm{H}_{2}, \mathrm{CH}_{3} \mathrm{OH}$, rt, 6 h; (f) HOBt/DCC, DMF, rt, 8 h; (g) NaOH, CH $\mathrm{HH}_{3} \mathrm{H} \mathrm{H}_{2} \mathrm{O}, \mathrm{DMF}, \mathrm{rt}, 1.5 \mathrm{~h}$, then $\mathrm{HCl}$ (aq.); (h) DMAP, DCC, CHCl $/$ DMF, rt, $28 \mathrm{~h}, 22 \%$.

Chart 1. Synthetic Route

a

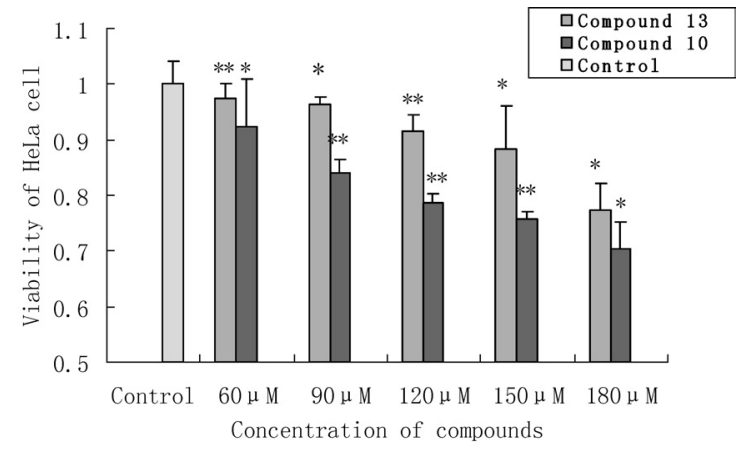

b

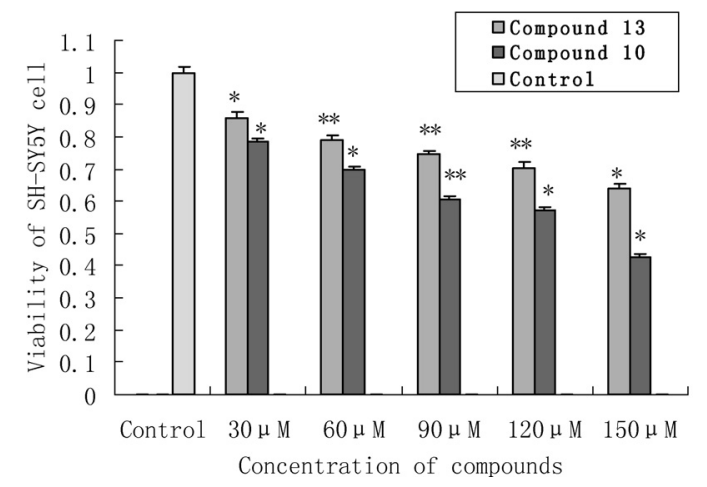

Fig. 1. Cytotoxicity of the Synthetic Compounds

(a) The viability of HeLa cells treated with polyamide $\mathbf{1 0}$ and conjugate $\mathbf{1 3}$ in different concentrations for $24 \mathrm{~h}$; (b) the viability of SH-SY5Y neuroblastoma cells treated with 10 and 13 in different concentrations for $22 \mathrm{~h}$. Values represent means \pm S.D. of three independent experiments. $* p<0.05$ and $* * p<0.01$.

sulted from the treatment of the synthetic compounds, apoptosis and cell cycle of HeLa were detected using flow cytometry (FCM) analysis. As shown in Fig. 3, apoptosis rates in-

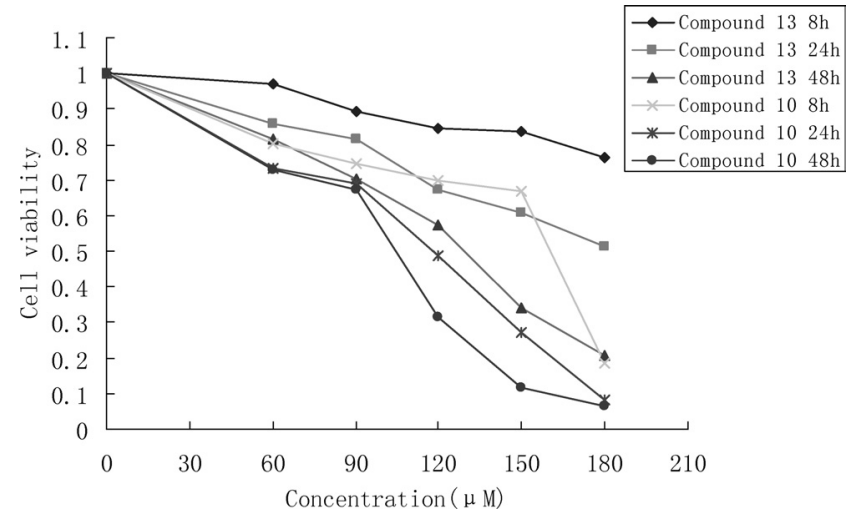

Fig. 2. Concentration- and Time-Dependent Cytotoxicity of the Compounds in HeLa Cells by MTT Assay

duced by the two compounds are almost at the same level indicating that both two compounds probably crossed the cell membrane and even the nuclear envelope, reached to and interacted with nucleic DNA, and then induced the HeLa cell apoptosis. However, the ratio of apoptosis/death induced by conjugate 13 was $94 \%$ at $150 \mu \mathrm{M}$, larger than that induced by polyamide $10(51 \%)$. Obviously, the cell death or the cytotoxicity induced by $\mathbf{1 3}$ was almost attributed to apoptosis but rather than necrosis. In contrast only about half of the cytotoxicity of $\mathbf{1 0}$ could be attributed to apoptosis. This result further revealed that the cytotoxicity of $\mathbf{1 3}$ was greatly lower than that of 10, and consequently suggests that some of biological functions of the phospholipid such as cytotoxicity reduction were combined with the polyamide in the conjugate.

The cell cycle of HeLa cells treated with $\mathbf{1 3}$ and $\mathbf{1 0}$ at the concentration of 120 and $150 \mu \mathrm{M}$ was also detected by FCM analysis. As shown in Table 1, it was observed that upon the 


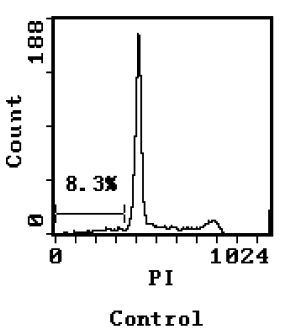

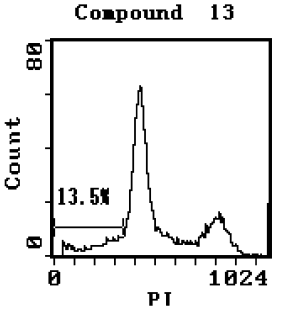

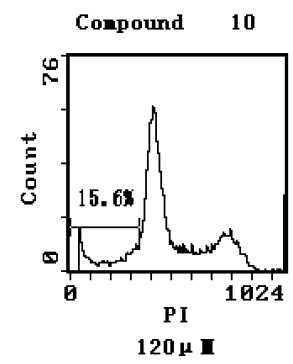

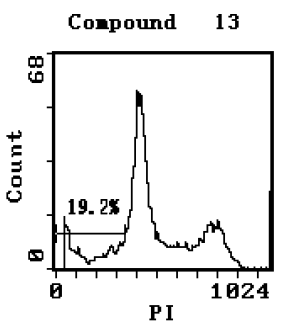

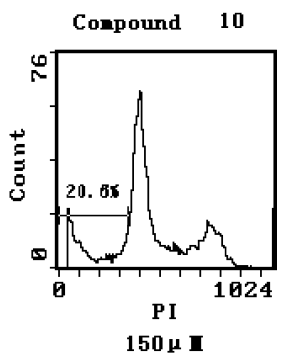

Fig. 3. Apoptosis Rate of HeLa Cells Treated with Polyamide $\mathbf{1 0}$ and Conjugate $\mathbf{1 3}$ for $24 \mathrm{~h}$

Table 1. The Cell Cycle Distribution after Treatment with $\mathbf{1 3}$ and $\mathbf{1 0}^{a)}$

\begin{tabular}{lccrc}
\hline \hline & $\mathrm{G}_{1}(\%)$ & $\mathrm{S}(\%)$ & $\mathrm{G}_{2}(\%)$ & $\mathrm{G}_{2} / \mathrm{G}_{1}$ \\
\hline Control & 68.6 & 24.1 & 7.4 & 1.918 \\
Compound 13 $(120 \mu \mathrm{M})$ & 53.7 & 26.5 & 19.8 & 1.934 \\
Compound 10 $(120 \mu \mathrm{M})$ & 53.1 & 30.7 & 16.2 & 1.930 \\
Compound 13 $(150 \mu \mathrm{M})$ & 47.9 & 32.9 & 19.1 & 1.932 \\
Compound 10 $(150 \mu \mathrm{M})$ & 51.3 & 28.0 & 20.7 & 1.917 \\
\hline
\end{tabular}

a) The influence the compounds on the cell cycle progression of HeLa cells cultured at $37^{\circ} \mathrm{C}$ for $24 \mathrm{~h}$.

treatment with $\mathbf{1 3}$ and $\mathbf{1 0}$ the G1 phase of the HeLa cell cycle was shorted whereas the $\mathrm{S}$ phase and $\mathrm{G} 2 / \mathrm{M}$ phase was prolonged, and thus the rate of G2/G1 was enlarged. Obviously, the cells were arrested in $\mathrm{S}$ and G2/M phase by both $\mathbf{1 3}$ and 10 indicating the compounds interfered with the DNA synthesis and subsequently delayed the mitosis. This demonstrated that the synthetic compounds interacted with nucleic DNA and supported the result of the apoptosis detection described above. Therefore, the results from the FCM analysis combined with that from the observation of cytotoxicity showed a great effect of the designed conjugate on the action in cells.

\section{Conclusion}

In summary, the cytotoxicity of the conjugate was lower than the native polyamide in HeLa cells and SH-SY5Y cells, although both of them could induce the apoptosis of the cells in almost same level. It has been known that the toxicity of polyamide has limited their use in pharmacological and clinical studies. ${ }^{19)}$ It is reasonable to presume that the greatly reduced cytotoxicity by the phospholipid-containing conjugate might be resulted from the nontoxic property of the phospholipid or from an improved movement of the conjugate through the cytoplasm in its pass toward to the nuclei, because the stay of unconjugated polyamide in the cytoplasm may be harmful to the organelles. Direct evidence for the mechanism of the cytotoxicity decreace has not obtained. However, the greatly reduced cytotoxicity may lead to an enhancement of specificity of the synthetic conjugate for reaching or binding to DNA target, and therefore is beneficial to the their use in molecular probe or drug design. Also, the conjugate synthsis have proven an effective way to design multifunctional molecules, although the mechanism of the cellular effect of the synthetic conjugate remains studied in more details. In order to develop the mechanism we are in the progress of studying the action of the synthetic compounds in cells by the method of fluorescent label of the compounds.

\section{Experimental}

General ${ }^{1} \mathrm{H}-\mathrm{NMR}$ spectra were recorded on a JEOR AL-300 spectrometer using DMSO- $d_{6}$ as a solvent unless otherwise specified. Electrospray ionization mass spectra (ESI-MS) were acquired using a Bruker ESQUIRE 3000 ion trap spectrometer equipped with a gas nebulizer probe. High resolution mass spectra were determined using an Auto Spec Ultima-TOF (Micromass, U.K.) for FAB-HR-MS, and a Q-Trap LC/MS/MS System, Turbo ionspray source (Applied Biosystems/MDS Sciex, U.S.A.) for ESI-HR-MS. Thin-layer chromatography was performed using Merck F254 silica gel plates. Column chromatography was performed using $200-$ 300 mesh silica gel. Lysophosphotidylcholine (lyso-PC) was purchased from Avanti polar-lipids, INC. Dimethyl sulfoxide (DMSO), MTT (3-[4,5-dimethylthiazol-2-yl]-2,5-diphenyl-tetrazolium bromide), trypan blue, and other chemicals were purchased from Sigma Industries. PI and RNAase A were purchased from Dingguo Company (China).

Cell Cultures HeLa cells were cultured as monolayers and maintained at $37^{\circ} \mathrm{C}$ in a humidified incubator with $5 \% \mathrm{CO}_{2}$ in DMEM (Gibco) supplemented with $10 \%$ fetal bovine serum (Wuhan Sanli Company) and 100 units $/ \mathrm{ml}$ penicillin-streptomycin. Cells $\left(4 \times 10^{4}\right)$ were cultured in 96well microtiter plates, and incubated for $24 \mathrm{~h}$ to allow cells to adhere. Compound $\mathbf{1 0}$ and compound $\mathbf{1 3}$ were freshly dissolved in DMSO, diluted to $600,900,1200,1500,1800 \mu \mathrm{M}$ with distilled water, and added pre-warmed cell culture media to a final concentration of $60,90,120,150,180 \mu \mathrm{M}$, and cells were then incubated in this media for an additional $24 \mathrm{~h}$ as before.

SH-SY5Y neuroblastoma cells were cultured as monolayers and maintained at $37^{\circ} \mathrm{C}$ in a humidified incubator with $5 \% \mathrm{CO}_{2}$ in DMEM (Gibco) supplemented with $10 \%$ fetal bovine serum (Wuhan Sanli Company) and 100 units $/ \mathrm{ml}$ penicillin-streptomycin. Cells $\left(2.5 \times 10^{5}\right)$ were cultured in 96well microtiter plates, and incubated for $24 \mathrm{~h}$ to allow cells to adhere. Freshly DMSO-dissolved compound $\mathbf{1 0}$ and compound $\mathbf{1 3}$ were diluted to $300,600,900,1200$, and $1500 \mu \mathrm{M}$ with distilled water and added prewarmed cell culture media to a final concentration of $30,60,90,120$, and $150 \mu \mathrm{M}$, and cells were then incubated in this media for an additional $22 \mathrm{~h}$ as before.

Cytotoxicity Assays The number of surviving cells was then counted by using the tetrazolium (MTT) assay. Twenty-two microliters aqueous MTT solution $(5 \mathrm{mg} / \mathrm{ml})$ was then added to each well $(220 \mu \mathrm{l})$, and the mixture was incubated at $37^{\circ} \mathrm{C}$ for $4 \mathrm{~h}$. The MTT solution was carefully decanted off, and formazan was extracted from the cells with $200 \mu 1$ DMSO in each 
well. Colour was measured with a Microplate reader at $570 \mathrm{~nm}$. All MTT assays were repeated three times.

FCM Analysis After appropriate treatment, HeLa cells $\left(4 \times 10^{4}\right.$ cells well) were harvested by centrifugation and washed with PBS. The cells were fixed with $4{ }^{\circ} \mathrm{C} 70 \%$ ethanol for $15 \mathrm{~h}$, washed with PBS, and then treated with $0.25 \mathrm{ml}$ of $0.5 \%$ Triton X-100 solution containing $1.0 \mathrm{mg} / \mathrm{ml}$ RNase A at $37^{\circ} \mathrm{C}$ for $30 \mathrm{~min}$. Finally, $0.25 \mathrm{ml}$ of $50 \mu \mathrm{g} / \mathrm{ml}$ propidium iodide was added to the sample for $30 \mathrm{~min}$ in the dark. Samples were run through a FACScan (Coulter). Results are presented as the number of cells versus the amount of DNA as indicated by the intensity of fluorescence.

$\mathbf{O}_{2}$ NPy $\beta$ OEt (5) Hydrochloric acid salt of ethyl $\beta$-alanine $(5.526 \mathrm{~g}$, $36 \mathrm{mmol}$ ) was added to $150 \mathrm{ml}$ of ethyl acetate, followed by the addition of TEA $(8 \mathrm{ml})$ under ultrasonic wave. After filtering off the $\mathrm{HCl}$ salt of TEA, 1 $(5.00 \mathrm{~g}, 18 \mathrm{mmol})$ was added. The solution was stirred overnight. Another $50 \mathrm{ml}$ of ethyl acetate was added. The organic layer was washed with brine, dried over anhydrous $\mathrm{MgSO}_{4}$, filtered, and concentrated in vacuo. After recrystallization from $80 \mathrm{ml}$ of ethanol, $4.52 \mathrm{~g}$ of flake crystalline $\mathbf{5}$ was obtained (93\% yield). IR (KBr) 3361, 3129, 1713, 1656, 1532, 1420 , $1193 \mathrm{~cm}^{-1} ;{ }^{1} \mathrm{H}-\mathrm{NMR}\left(\mathrm{CDCl}_{3}, 200 \mathrm{MHz}\right) \delta 7.56\left(\mathrm{~d}, 1 \mathrm{H},{ }^{4} J(\mathrm{H}, \mathrm{H})=1.2 \mathrm{~Hz}\right)$ $7.08\left(\mathrm{~d}, 1 \mathrm{H},{ }^{4} J(\mathrm{H}, \mathrm{H})=0.8 \mathrm{~Hz}\right), 6.76(\mathrm{~s}, 1 \mathrm{H}), 4.20\left(\mathrm{q}, 2 \mathrm{H},{ }^{3} J(\mathrm{H}, \mathrm{H})=7.2 \mathrm{~Hz}\right)$, $3.99(\mathrm{~s}, 3 \mathrm{H}), 3.65\left(\mathrm{q}, 2 \mathrm{H},{ }^{3} J(\mathrm{H}, \mathrm{H})=6.2 \mathrm{~Hz}\right), 2.62\left(\mathrm{t}, 2 \mathrm{H},{ }^{3} J(\mathrm{H}, \mathrm{H})=5.8 \mathrm{~Hz}\right)$, $1.29\left(\mathrm{t}, 3 \mathrm{H},{ }^{3} J(\mathrm{H}, \mathrm{H})=7.2 \mathrm{~Hz}\right)$; MS (EI) $m / z 269\left(\mathrm{M}^{+}\right)$.

$\mathrm{O}_{2}$ NPy $\boldsymbol{\beta}$ OMe (4) A synthetic procedure similar to that for $\mathbf{5}$ was followed for the preparation of 4 ( $87 \%$ yield).

$\mathrm{O}_{2}$ NPyPy $\boldsymbol{\beta O M e}(6)$ To a solution of $\mathrm{O}_{2} \mathrm{NPyCOOH}(0.510 \mathrm{~g}, 3 \mathrm{mmol})$ in $30 \mathrm{ml}$ of $\mathrm{CHCl}_{3}$ and $10 \mathrm{ml}$ DMF was added HOBt $(0.608 \mathrm{~g}, 4.5 \mathrm{mmol})$, and solution of DCC $(1.547 \mathrm{~g}, 7.5 \mathrm{mmol})$ in $10 \mathrm{ml} \mathrm{CHCl}_{3}$. The reaction solution was stirred overnight at $\mathrm{rt}$ and DCU was removed by filtration. Separately, to a solution of $4(0.765 \mathrm{~g}, 3 \mathrm{mmol})$ in $100 \mathrm{ml}$ of $\mathrm{EtOH}$ was added $\mathrm{Pd} / \mathrm{C}$ catalyst $(10 \%, 0.076 \mathrm{~g})$. The mixture was stirred under a slight positive pressure of $\mathrm{H}_{2}$ overnight. The catalyst was removed by filtration through Celite, and the filtrate was concentrated in vacuo to remove the EtOH. The filtrate was directly added into the reaction solution prepared above. The mixture was stirred for $24 \mathrm{~h}$ at $\mathrm{rt}$, and then was concentrated in vacuo. After purification by column chromatography with an eluent of $\mathrm{CHCl}_{3}: \mathrm{CH}_{3} \mathrm{OH}$ (15:1), $0.905 \mathrm{~g}$ of product (6) was obtained ( $85 \%$ yield). $R f=0.52$ ( $\mathrm{Si}$ gel, $\left.\mathrm{CHCl}_{3}: \mathrm{CH}_{3} \mathrm{OH}, 15: 1\right) ;{ }^{1} \mathrm{H}-\mathrm{NMR}\left(\mathrm{CDCl}_{3}, 400 \mathrm{MHz}\right) \delta 7.19(\mathrm{~s}, 1 \mathrm{H}), 7.17(\mathrm{~s}$, $1 \mathrm{H}), 7.00(\mathrm{~s}, 1 \mathrm{H}), 6.50(\mathrm{~s}, 1 \mathrm{H}), 4.03(\mathrm{~s}, 3 \mathrm{H}), 3.92(\mathrm{~s}, 3 \mathrm{H}), 3.72(\mathrm{~s}, 3 \mathrm{H}), 3.50$ $(\mathrm{m}, 2 \mathrm{H}), 2.63\left(\mathrm{dd}, 2 \mathrm{H},{ }^{3} J(\mathrm{H}, \mathrm{H})=6.0 \mathrm{~Hz}\right)$. MS (ESI): $m / z: 378[\mathrm{M}+\mathrm{H}]^{+}$.

$\mathbf{O}_{2}$ NPyPy $\beta$ COOH (7) To a solution of $\mathrm{O}_{2} \mathrm{NPyPyCOOMe}(0.188 \mathrm{~g}$, $0.510 \mathrm{mmol})$ in $60 \mathrm{ml}$ of ethanol was added $\mathrm{NaOH}(0.200 \mathrm{~g}$ in $10 \mathrm{ml}$ of water). The reaction solution was stirred at room temperature overnight. The solution was concentrated in vacuo to remove the ethanol solvent. The $\mathrm{pH}$ of the remaining aqueous solution was adjusted to about 2 by adding $6 \mathrm{~N} \mathrm{HCl}$. The precipitate was collected by filtration and was washed with water and dried under an IR lamp to offer $0.166 \mathrm{~g}$ of 7 (92\% yield).

$\mathrm{O}_{2}$ NPyPy $\beta$ OEt (8) A synthetic procedure similar to that for 6 was followed for the preparation of $\mathbf{8}$ ( $55 \%$ yield).

$\mathrm{O}_{2}$ NPyPy $\boldsymbol{\beta}$ PyPy $\boldsymbol{\beta}$ COOH (11) A synthetic procedure similar to that for 7 was followed for the preparation of $\mathbf{1 1}$ (95\% yield).

$\mathrm{O}_{2}$ NPyPy $\boldsymbol{\beta}$ PyPy $\boldsymbol{\beta}$ OEt (10) To a solution of $\mathrm{O}_{2} \mathrm{NPyPy} \beta \mathrm{COOH}$ (7) $(0.432 \mathrm{~g}, 1.162 \mathrm{mmol})$ in $10 \mathrm{ml}$ of DMF was added $\mathrm{HOBt}(0.236 \mathrm{~g}$, $1.744 \mathrm{mmol})$, and solution of DCC $(1.201 \mathrm{~g}, 5.812 \mathrm{mmol})$ in $10 \mathrm{ml} \mathrm{CHCl}_{3}$. The reaction solution was stirred overnight at $\mathrm{rt}$ and DCU was removed by filtration. Separately, to a solution of $\mathrm{O}_{2} \mathrm{NPyPy} \beta \mathrm{OEt}(\mathbf{8})(0.303 \mathrm{~g}$, $0.7749 \mathrm{mmol})$ in $10 \mathrm{ml}$ of DMF was added $\mathrm{Pd} / \mathrm{C}(20 \%, 0.060 \mathrm{mg})$, and the mixture was stirred at $\mathrm{rt}$ under a slight positive pressure of $\mathrm{H}_{2}$ overnight. The catalyst was removed by filtration through Celite, and the filtrate $\mathrm{H}_{2} \mathrm{NPyPy} \beta \mathrm{OEt}(9)$ was directly added into the reaction solution prepared above. The mixture was stirred for $30 \mathrm{~h}$ at $\mathrm{rt}$, and then was concentrated in vacuo. After purification by column chromatography with an eluent of $\mathrm{CHCl}_{3}: \mathrm{CH}_{3} \mathrm{OH}: \mathrm{NH}_{3} \cdot \mathrm{H}_{2} \mathrm{O}(90: 10: 1), 0.450 \mathrm{~g}$ of product (10) was obtained $\left(85.9 \%\right.$ yield). $R f=0.26 \quad\left(\mathrm{Si}\right.$ gel, $\mathrm{CHCl}_{3}: \mathrm{CH}_{3} \mathrm{OH}: \mathrm{NH}_{3} \cdot \mathrm{H}_{2} \mathrm{O}$ $90: 10: 1)$. The purity of product was $99.7 \%$ which was verified by analytical HPLC. ${ }^{1} \mathrm{H}-\mathrm{NMR}$ (DMSO- $\left.d_{6}, 300 \mathrm{MHz}\right) \delta 10.23(\mathrm{~s}, 1 \mathrm{H} ; \mathrm{NH}), 9.98(\mathrm{~s}$, $1 \mathrm{H}, \mathrm{NH}), 9.86(\mathrm{~s}, 1 \mathrm{H}, \mathrm{NH}), 8.16\left(\mathrm{~d}, 1 \mathrm{H},{ }^{4} J(\mathrm{H}, \mathrm{H})=1.2 \mathrm{~Hz} ; \mathrm{NO}_{2} \mathrm{CCH}\right.$ ), $8.12\left(\mathrm{t}, 1 \mathrm{H},{ }^{3} J(\mathrm{H}, \mathrm{H})=4.8 \mathrm{~Hz} ; \mathrm{NH}\right), 8.06\left(\mathrm{t},{ }^{3} J(\mathrm{H}, \mathrm{H})=4.8 \mathrm{~Hz}, 1 \mathrm{H} ; \mathrm{NH}\right)$, $7.56\left(\mathrm{~d},{ }^{4} J(\mathrm{H}, \mathrm{H})=1.5 \mathrm{~Hz}, 1 \mathrm{H} ; \mathrm{NO}_{2} \mathrm{CC} \underline{\mathrm{HC}}\right), 7.21\left(\mathrm{~d},{ }^{4} J(\mathrm{H}, \mathrm{H})=0.9 \mathrm{~Hz}\right.$, $1 \mathrm{H} ; \mathrm{NHCCHN}), 7.17\left(\mathrm{~d},{ }^{4} J(\mathrm{H}, \mathrm{H})=1.5 \mathrm{~Hz}, 2 \mathrm{H} ; 2 \times \mathrm{NHCCHN}\right), 6.84(\mathrm{~d}$, $\left.{ }^{4} J(\mathrm{H}, \mathrm{H})=0.9 \mathrm{~Hz}, \quad 1 \mathrm{H} ; \quad \mathrm{NHCC} \underline{\mathrm{HC}}\right), \quad 6.82 \quad\left(\mathrm{~d}, \quad{ }^{4} J(\mathrm{H}, \mathrm{H})=1.2 \mathrm{~Hz}, \quad 2 \mathrm{H}\right.$; $2 \times \mathrm{NHCCHC}), 4.06\left(\mathrm{q},{ }^{3} \mathrm{~J}(\mathrm{H}, \mathrm{H})=6.9 \mathrm{~Hz}, 2 \mathrm{H} ; \mathrm{OCH}_{2} \mathrm{CH}_{3}\right), 3.93(\mathrm{~s}, 3 \mathrm{H}$; $\left.\mathrm{NCH}_{3}\right), 3.81\left(\mathrm{~s}, 6 \mathrm{H} ; 2 \times \mathrm{NC}_{3}\right), 3.78\left(\mathrm{~s}, 3 \mathrm{H} ; \mathrm{NC}_{3}\right), 3.42(\mathrm{~m}, 2 \mathrm{H}$; $\left.\mathrm{NHCH}_{2} \mathrm{CH}_{2}\right), 3.32\left(\mathrm{~m}, 2 \mathrm{H} ; \mathrm{NHCH}_{2} \mathrm{CH}_{2}\right), 2.53\left(\mathrm{t},{ }^{3} \mathrm{~J}(\mathrm{H}, \mathrm{H})=6.8 \mathrm{~Hz}, 4 \mathrm{H}\right.$; $\left.2 \times \mathrm{NHCH}_{2} \underline{\mathrm{H}}_{2} \mathrm{CO}\right), 1.17\left(\mathrm{t},{ }^{3} \mathrm{~J}(\mathrm{H}, \mathrm{H})=6.9 \mathrm{~Hz}, 3 \mathrm{H} ; \mathrm{CH}_{2} \underline{\mathrm{CH}}_{3}\right) . \mathrm{MS}(\mathrm{ESI})$ : $m / z: 706.8[\mathrm{M}+\mathrm{H}]^{+}$. HR-MS $\left(\mathrm{FAB}^{+}\right)$Calcd for $\mathrm{C}_{32} \mathrm{H}_{39} \mathrm{~N}_{10} \mathrm{O}_{9}\left(\mathrm{M}+\mathrm{H}^{+}\right)$ 707.2901, Found 707.2924

$\mathrm{O}_{2} \mathrm{NPyPy} \boldsymbol{\beta}$ PyPy $\boldsymbol{\beta}$ PC (13) To a solution of $\mathrm{O}_{2} \mathrm{NPyPy} \beta \mathrm{PyPy} \beta \mathrm{COOH}$ (11) $(103 \mathrm{mg}, 0.152 \mathrm{mmol})$ in $20 \mathrm{ml}$ of $\mathrm{CHCl}_{3}$ and $2 \mathrm{ml} \mathrm{DMF}$ was added DMAP $(28 \mathrm{mg}, 0.229 \mathrm{mmol})$, DCC $(100 \mathrm{mg}, 0.485 \mathrm{mmol})$, and lyso-PC $(52 \mathrm{mg}, 0.101 \mathrm{mmol})$ at $\mathrm{rt}$, and the mixture was stirred at $\mathrm{rt}$ for $28 \mathrm{~h}$. The resulting mixture was concentrated in vacuo to give a crude residue, which was then purified by chromatography ( $\mathrm{Si}$ gel, $\mathrm{CHCl}_{3}: \mathrm{CH}_{3} \mathrm{OH}: \mathrm{NH}_{3} \cdot \mathrm{H}_{2} \mathrm{O}$, $80: 35: 2)$. Twenty-six milligrams of $\mathbf{1 3}$ was obtained $(22.2 \%$ yield $)$ $R f=0.35\left(\mathrm{Si}\right.$ gel, $\left.\mathrm{CHCl}_{3}: \mathrm{CH}_{3} \mathrm{OH}: \mathrm{NH}_{3} \cdot \mathrm{H}_{2} \mathrm{O}, 80: 35: 2\right)$. The purity of product was $96.0 \%$ which was verified by analytical HPLC. ${ }^{1} \mathrm{H}-\mathrm{NMR}$ (DMSO$\left.d_{6}, 300 \mathrm{MHz}\right) \delta 10.34(\mathrm{~s}, 1 \mathrm{H} ; \mathrm{NH}), 10.25(\mathrm{~s}, 1 \mathrm{H} ; \mathrm{NH}), 9.93(\mathrm{~s}, 1 \mathrm{H} ; \mathrm{NH})$, $8.16\left(\mathrm{~d},{ }^{4} J(\mathrm{H}, \mathrm{H})=1.2 \mathrm{~Hz}, 1 \mathrm{H} ; \quad \mathrm{NO}_{2} \mathrm{CCHN}\right), 8.11 \quad\left(\mathrm{t},{ }^{3} J(\mathrm{H}, \mathrm{H})=4.8 \mathrm{~Hz}\right.$, $1 \mathrm{H} ; \mathrm{NH}), 7.58\left(\mathrm{~d},{ }^{4} J(\mathrm{H}, \mathrm{H})=1.5 \mathrm{~Hz}, 1 \mathrm{H} ; \mathrm{NO}_{2} \mathrm{CCHC}\right), 7.26\left(\mathrm{~d},{ }^{4} J(\mathrm{H}, \mathrm{H})=\right.$ $0.9 \mathrm{~Hz}, 1 \mathrm{H} ; \mathrm{NHCCHN}), 7.23\left(\mathrm{~d},{ }^{4} J(\mathrm{H}, \mathrm{H})=0.9 \mathrm{~Hz}, 1 \mathrm{H} ; \quad \mathrm{NHCCHN}\right)$ $7.17\left(\mathrm{~d},{ }^{4} J(\mathrm{H}, \mathrm{H})=0.9 \mathrm{~Hz}, 1 \mathrm{H}\right.$; NHCCHN $), 6.87\left(\mathrm{~d},{ }^{4} J(\mathrm{H}, \mathrm{H})=0.9 \mathrm{~Hz}, 1 \mathrm{H}\right.$; $\mathrm{NHCCHC}), 6.83\left(\mathrm{~d},{ }^{4} J(\mathrm{H}, \mathrm{H})=1.2 \mathrm{~Hz}, 2 \mathrm{H} ; 2 \times \mathrm{NHCCHC}\right), 4.38(\mathrm{~m}, 1 \mathrm{H}$ $\left.\mathrm{OCH}_{2} \mathrm{CHCH}_{2} \mathrm{O}\right), 4.29$ (m, 2H; $\left.\mathrm{OPOCH}_{2}\right), 4.12\left(\mathrm{~m}, 1 \mathrm{H} ; \mathrm{OCH}_{2} \mathrm{CHCH}_{2} \mathrm{O}\right)$, 4.04 (s, 3H; $\left.\mathrm{NCH}_{3}\right), 3.94\left(\mathrm{~m}, 2 \mathrm{H} ; \mathrm{OCH}_{2} \mathrm{CHCH}_{2} \mathrm{O}\right), 3.81(\mathrm{~s}, 6 \mathrm{H} ; 2 \times$ $\left.\mathrm{NCH}_{3}\right), 3.77\left(\mathrm{~s}, 3 \mathrm{H} ; \mathrm{NCH}_{3}\right), 3.47\left(\mathrm{~m}, 2 \mathrm{H} ; \mathrm{NHCH}_{2} \mathrm{CH}_{2}\right), 3.33(\mathrm{~m}$, $\left.2 \mathrm{H} ; \mathrm{NHCH}_{2} \mathrm{CH}_{2}\right), 3.06\left(\mathrm{~s}, 9 \mathrm{H} ; 3 \times \mathrm{OCH}_{2} \mathrm{CH}_{2} \mathrm{NCH}_{3}\right), 2.49\left(\mathrm{t},{ }^{3} \mathrm{~J}(\mathrm{H}\right.$, $\left.\mathrm{H})=6.8 \mathrm{~Hz}, \quad 4 \mathrm{H} ; \quad 2 \times \mathrm{NHCH}_{2} \mathrm{CH}_{2} \mathrm{CO}\right), 2.26\left(\mathrm{q}, \quad{ }^{3} J(\mathrm{H}, \mathrm{H})=4.8 \mathrm{~Hz}, 2 \mathrm{H}\right.$; $\left.\mathrm{OCOCH}_{2} \mathrm{CH}_{2}\left(\mathrm{CH}_{2}\right)_{14} \mathrm{CH}_{3}\right), \quad 1.89\left(\mathrm{~m}, 2 \mathrm{H} ; \quad \mathrm{OCOCH}_{2} \mathrm{CH}_{2}\left(\mathrm{CH}_{2}\right)_{14} \mathrm{CH}_{3}\right)$, $1.34 \quad\left(\mathrm{~m}, \quad 2 \mathrm{H} ; \quad \mathrm{OCOCH}_{2} \mathrm{CH}_{2}\left(\mathrm{CH}_{2}\right)_{13} \mathrm{CH}_{2} \mathrm{CH}_{3}\right), \quad 1.22 \quad(\mathrm{~m}, \quad 26 \mathrm{H}$ $\left.\mathrm{OCOCH}_{2} \mathrm{CH}_{2}\left(\mathrm{CH}_{2}\right)_{13} \mathrm{CH}_{2} \mathrm{CH}_{3}\right), 0.83\left(\mathrm{~m}, 3 \mathrm{H} ; \mathrm{OCO}\left(\mathrm{CH}_{2}\right)_{16} \mathrm{CH}_{3}\right)$. MS (ESI): $m / z$ : $1184.6[\mathrm{M}+\mathrm{H}]^{+}$. HR-MS $\left(\mathrm{ESI}^{+}\right)$Calcd for $\mathrm{C}_{56} \mathrm{H}_{87} \mathrm{~N}_{11} \mathrm{O}_{15} \mathrm{P}\left(\mathrm{M}+\mathrm{H}^{+}\right)$ 1184.6121, Found 1184.6054.

Acknowledgements We thank the National Natural Science Foundation of China (No. 20372009) and National 973 Program of China (No. 2003CB514126) for the financial support.

\section{References}

1) Dickinson L. A., Gulizia R. J., Trauger J. W., Baird E. E., Mosier D. E., Gottesfeld J. M., Dervan P. B., Proc. Natl. Acad. Sci. U.S.A., 95 $12890-12895$ (1998).

2) Gottesfeld J. M., Neely L., Trauger J. W., Baird E. E., Dervan P. B., Nature (London), 387, 202-205 (1997).

3) Mapp A. K., Anasari A. Z., Ptashne M., Dervan P. B., Proc. Natl. Acad. Sci. U.S.A., 97, 3930-3935 (2000).

4) Crowley K. S., Phillion D. P., Woodard S. S., Schweitzer B. A., Singh M., Shabany H., Burnette B., Hippenmeyer P., Heitmeier M., Bashkin J. K., Bioorg. Med. Chem. Lett., 13, 1565-1570 (2003).

5) Putta M. R., Rachel R., Thomas C. B., Bioorg. Med. Chem. Lett., 14, 3803-3807 (2004).

6) Dervan P. B., Edelson B. S., Curr. Opin. Struct. Biol., 13, 284-299 (2003).

7) Best T. P., Edelson B. S., Nickols N. G., Dervan P. B., Biochemistry, 14, 12063-12068 (2003).

8) Janssen S., Durussel T., Laemmli U. K., Mol. Cell, 6, 999-1011 (2000).

9) Janssen S., Cuvier O., Muller M., Laemmli U. K., Cell, 6, 1013-1024 (2000).

10) Supekova L., Pezacki J., Su A. I., Loweth C. J., Riedl R., Geierstanger B., Schultz P. G., Wemmer D. E., Chem. Biol., 9, 821-827 (2002).

11) Belitsky J., Leslie S. J., Arora P. S., Beerman T. A., Dervan P. B., Bioorg. Med. Chem. Lett., 10, 3313-3318 (2002).

12) Dickinson L. A., Gulizia R. J., Trauger J. W., Baird E. E., Mosier D. E., Gottesfeld J. M., Dervan P. B., Proc. Natl. Acad. Sci. U.S.A., 95, $12890-12895$ (1998).

13) Anthony N. G., Fox K. R., Johnston B. F., Khalaf A. I., Mackay S. P., McGroarty I. S., Parkinson J. A., Skellern G. G., Suckling C. J., Waigh R. D., Bioorg. Med. Chem. Lett., 14, 1353-1356 (2004).

14) Dervan P. B., Bioorg. Med. Chem., 9, 2215-2235 (2001).

15) Melander C., Burnett R., Gottesfeld J. M., J. Biotec., 112, 195-220 (2004).

16) Kopka M. L., Yoon C., Goodsell D., Pjura P., Dickerson R. E., Proc. Natl. Acad. Sci. U.S.A., 82, 1376-1380 (1985).

17) Pelton J. G., Wemmer D. E., Proc. Natl. Acad. Sci. U.S.A., 86, 5723 5727 (1989).

18) Xiao J. H., Yuan G., Huang W. Q., J. Org. Chem., 65, 5506-5513 (2000).

19) Zimmer C., Wahnert U., Prog. Biophys. Molec. Biol., 47, 31-112 (1986). 